\title{
SATUAN POLISI PAMONG PRAJA DAN WILAYATUL HISBAH DALAM PENEGAKAN QANUN DI KABUPATEN ACEH BARAT
}

\author{
Apri Rotin Djusfi ${ }^{1)}$, Cut Rina ${ }^{2)}$ \\ Fakultas Ilmu Sosial dan Ilmu Politik Universitas Teuku Umar \\ aprirotin87@gmail.com \\ Cutrina63@yahoo.co.id
}

\begin{abstract}
The purpose of this research is to know the duties and functions of civil service police unit and wilayatul hisbah in enforcing qanun. Determination of the sample is done by purposive sampling method The research method used qualitative descriptive research. Data collection techniques used three ways: observation, interview, and documentation. The results showed that the tasks of Satuan Pamong Praja Police Unit essentially bind the relationship between members / groups / members of society with the government, basically the three pillars that are related to each other and can not be separated. The three pillars are: First, tranquility is a feeling of the soul of a person (community member) who enjoys his life comfortably free from both physical and spicical disturbances and threats. All activities, creativity, productivity of citizens can be done without fear of fear and worry. Second, peace is an order in a living environment manifested by the existence of human behavior, both personal and as a member of society that adheres to the rules of religious norms, social norms and applicable legislation. Thirdly, the enforcement of regulations (including norms and values) is an important means for the realization of order. Satpol PP and WH Kabupaten Aceh Barat have the task of upholding Qanun and organizing peace and public order and protection of society and enforcement of syariat islam.
\end{abstract}

Keywords: Civil Service Police Unit, the WH, Enforcement Qanun 


\section{PENDAHULUAN}

Globalisasi merupakan sebuah fenomena dimana negara-negara di dunia secara langsung maupun tidak langsung mengharapkan terjadinya interaksi antar masyarakat yang jauh lebih efektif dan efisien dibandingkan dengan saat-saat sebelumnya. Pada era globalisasi tersebut semakin menampakkan kepentingan tatkala pintu Otonomi melalui Undang-Undang Nomor 9 Tahun 2015 tentang perubahan kedua atas Undang-Undang Nomor 23 Tahun 2014 Tentang Pemerintahan Daerah semakin terbuka lebar. Pada keadaan ini semua sektor lini pada pemerintahan sangat dibutuhkan dalam hal menciptakan suatu sistem tata kelola pemerintahan yang baik. Salah satu lembaga yang sangat berperan dalam mendukung terciptanya prinsip pemerintahan yang baik dilingkungan pemerintahan daerah adalah Satuan Polisi Pamong Praja (Satpol PP) dan Wilayatul Hisbah (WH).

Pada masa penjajahan Belanda Satuan Polisi Pamong Praja dikenal dengan nama Bailluw (berasal dari bahasa jawa) dan telah beberapa kali berganti nama menjadi kepanewon serta Detasemen Polisi Pamong Praja, baru kemudian pada Tahun 1950 melalui Surat Keputusan Menteri Dalam Negeri Nomor UR 32/2/21 Tanggal 3 Maret 1950 Tentang Perubahan Nama Detasemen Polisi Pamong Praja menjadi Satuan Polisi Pamong Praja, dimana selanjutnya tanggal 3 Maret ini dijadikan hari lahirnya Satpol PP dan untuk diperingati pada setiap tahunnya. Polisi Pamong Praja adalah sebuah organisasi yang hubungannya sangat erat dengan masyarakat karena fungsi utamanya adalah menjaga ketertiban umum danketentraman masyarakat. Istilah Pamong Praja adalah sebuah kata yang diambil dari bahasa jawa yang mengandung arti filosofis cukup mendalam, Pamong adalah seseorang yang dipandang, dituakan dan dihormati sehingga memiliki fungsi sebagai pembina masyarakat diwilayahnya. Selanjutnya makna dari kata Praja adalah rakyat/ masyarakatnya. Dapat disimpulkan Pamong Praja yaitu petugas atau individu yang dihormati guna membina masyarakat diwilayahnya agar tertib dan tentram.

Di Kabupaten Aceh Barat cikal Satuan Polisi Pamong Praja diawali dengan sebuah Sub Bagian Ketertiban pada Bagian Pemerintahan Setdakab Aceh Barat, pada Tahun 1999 ditingkatkan statusnya menjadi Bagian Ketertiban pada Setdakab Aceh Barat yang sekaligus membawahi Satpol PP baru kemudian pada Tahun 2003 melalui Peraturan Daerah Kabupaten Aceh Barat Nomor 2 Tahun 2003 Tentang Pembentukan Susunan Organisasi dan Tata Kerja Dinas-dinas Daerah Kabupaten Aceh Barat, kelembagaan Bagian Ketertiban dipindahkan dari Setdakab Aceh Barat ke Dinas Kebersihan, Penertiban dan Lingkungan Hidup dan berulah berubah dari Bagian menjadi sebuah Bidang.

Baru pada Tahun 2008 kelembagaan Bidang Ketertiban diubah menjadi Satuan Polisi Pamong Praja dan digabungkan dengan Satuan Wilayatul hisbah melalui Qanun Kabupaten Aceh Barat Nomor 4 Tahun 2008 Tentang Pembentukan Susunan Organisasi dan Tata Kerja Lembaga Teknis Daerah Kabupaten Aceh Barat dan Peraturan Bupati Aceh Barat Nomor 13 Tahun 2008 Tentang Penjabaran, Tugas, Fungsi dan Tata Kerja Satuan Polisi Pamong Praja dan Wilayatul Hisbah Kabupaten Aceh Barat.

Pada Tahun 2004 melalui Keputusan Gubernur Provinsi Nangroe Aceh Darussalam Nomor 01 Tahun 2004 Tentang Pembentukan Organisasi dan Tata Kerja Wilayatul Hisbah, dibentuklah sebuah organisasi kelembagaan baru di Provinsi Aceh yang bernama Wilayatul Hisbah, namun mengingat ini merupakan sebuah organisasi baru yang dibentuk sebagai upaya untuk melakukan tugas pengawasan dan pembinaan terhadap orang-orang yang melakukan pelanggaran terhadap peraturan perundang-undangan dibidang syariat islam sebelum dilakukan proses penyidikan, maka untuk sementara organisasi dijadikan sebuah Bidang dan digabung pada Dinas Syariat Islam Provinsi Aceh pada Tahun 2005. Dulu Wilayatul Hisbah hanya bermodalkan keputusan Gubernur dan tunduk di bawah naungan Dinas Syariat Islam, akan tetapi setelah lahirnya Undang-Undang Nomor 11 Tahun 2006 Tentang Pemerintahan Aceh, maka Wilayatul Hisbah 
(WH) merupakan bagian dari Satuan Polisi Pamong Praja (Satpol PP) sebagaimana dimaksud dalam Undang-Undang Pemerintah Aceh Pasal 244 ayat (2) (UU Nomor 11 Tahun 2006).

Undang-Undang Nomor 9 Tahun 2015 tentang perubahan kedua atas Undang-Undang Nomor 23 Tahun 2014 Tentang Pemerintahan Daerah yang mengamanatkan dibentuknya Satpol PP, dan sudah digabungkan dengan Wilayatul Hisbah tujuannya untuk membantu kepala daerah dalam penegakan Peraturan Daerah dan penyelenggaraan ketertiban umum, serta ketentraman masyarakat berdasarkan Peraturan Pemerintah Republik Indonesia Nomor 6 Tahun 2010 Tentang Satuan Polisi Pamong Praja Pasal 1 ayat (8).

Fungsi Satpol PP itu sendiri sangat mencangkup pada fungsi operasi, fungsi koordinasi dan juga fungsi pengawasan, ini menunjukkan betapa pentingnya dan strategisnya peran Satpol PP dalam menyangga kewibawaan pemerintahan daerah dan penciptaan situasi kondusif dalam kehidupan pembangunan bangsa. Meskipun Satpol PP dan WH telah menjalankan tugas dan melakukan berbagai antisipasi terhadap orang-orang yang melanggar aturan, namun tetap terjadi permasalahan dalam kinerjanya dan salah satu masalah yang terjadi sekarang adalah masalah Pedagang Kaki Lima, dan ini menjadi salah satu tugas Satpol PP dan WH dalam menanganinya sebagaimana tugas dan fungsi dari Satpol PP da WH itu sendiri.

\section{METODOLOGI PENELITIAN}

Metode penelitian yang digunakan untuk memahami secara mendalam tentang penelitian ini adalah penelitian deskriptif dengan pendekatan Kualitatif. Memberikan pengertian penelitian deskriptif sebagai penelitian yang berusaha untuk menuturkan pemecahan masalah yang ada sekarang berdasarkan data-data; ia juga menyajikan data, menganalisis dan menginterprestasi; ia juga bisa bersifat komperatif dan koleratif (Narbuko \& Ahmadi, 2004).

Dipilihnya pendekatan kualitatif tersebut dikarenakan masalah yang akan diteliti masih bersifat kompleks, dinamis dan bertujuan untuk memahami fenomena sosial serta tidak bermaksud generalisasi. Dengan dugunakan pendekatan kualiatatif, maka data yang didapat akan lebih lengkap, lebih mendalam, kredibel, dan bermakna sehingga penelitian dapat tercapai (Sugiyono, 2005: 181). Taylor dan Bogdam dalam Danim (2002, h. 41). "mengatakan bahwa penelitian kualitatif dapat diartikan sebagai penelitian yang menghasilkan data deskriptif mengenai kata-kata lisan maupun tertulis, dan tingkah laku yang dapat diamati dari orang-orang yang diteliti ". Danim, memberikan beberapa ciri dominan dari penelitian deskriptif yaitu (Danim, 2002:41):

1. Bersifat mendeskripsikan kejadian atau peristiwa yang bersifat faktual. Adakalanya penelitian ini dimaksudkan hanya membuat deskripsi atau narasi semata-mata dari suatu fenomena, tidak untuk mecari hubungan antar variabel, menguji hipotesis, atau membuat ramalan.

2. Dilakukan secara survei. Oleh karena itu penelitian deskriptif sering dibuat juga sebagai penelitian survei. Dalam arti luas, penelitian deskriptif dapat mencakup seluruh metode penelitian, kecuali yang berifat historis dan eksperimental.

3. Bersifat mencari informasi faktual dan dilakukan secara mendetail.

4. Mengindentifikasi masalah-masalah untuk mendapatkan keadaan dan praktek-praktek yang sedang belangsung; dan

5. Mendeskrpsikan subjek yang sedang dikelola oleh kelompok orang tertentu dalam waktu yang bersamaan.

\section{HASIL PENELITIAN DAN PEMBAHASAN \\ Defenisi Polisi Pamong Praja}

Istilah Polisi pamong praja berasal dari dua kata yaitu "Pamong dan Praja" Pamong mempunyai arti pengurus, pengasus atau pendidik, sedangkan praja yang berarti kota, negeri 
atau kerajaan. Secara harfiah pamong praja dapat diartikan sebagai pengurus kota, menurut Hasan (2005, h. 817)

Satuan Polisi Pamong Praja disingkat Satpol PP, adalah perangkat Pemerintah Daerah dalam memelihara ketentraman dan ketertiban umum serta menegakkan Peraturan Daerah. Organisasi dan tata kerja satuan polisi pamong praja ditetapkan dengan peraturan daerah Satpol PP dapat berkedudukan di Daerah Provinsi dan Daerah /Kota.

Definisi lain Polisi adalah Badan Pemerintah yang bertugas memelihara keamanan dan ketertiban umun atau Pegawai Negara yang bertugas menjaga keamanan, menurut Hasan (2005, h. 886)

Satuan Polisi Pamong Praja (Satpol PP) merupakan suatu perangkat pemerintah khususnya didaerah dengan tugasnya adalah membantu kepala daerah untuk menyelenggarakan peraturan daerah serta menjaga ketertiban dan ketentraman masyarakat. Diberikannya kewenangan pada Satpol PP untuk melaksanakan tugas pemeliharaan dan penyelenggaraan ketenteraman dan ketertiban umum tidak saja berpijak dari Undang-undang No. 2 Tahun 2002 tentang Kepolisian Negara Republik Indonesia.

Tetapi ada juga amanat dari Pasal 13 huruf c dan Pasal 14 huruf c Undang-undang No. 23 Tahun 2014 Tentang Pemerintahan Daerah, yang pada pokoknya menyebutkan: Urusan wajib yang menjadi kewenangan pemerintahan daerah (provinsi, kabupaten/kota) adalah penyelenggaraan ketertiban umum dan ketenteraman masyarakat. Ketertiban umum dan ketenteraman masyarakat adalah suatu keadaan dimana pemerintah maupun masyarakat umum menjalankan segala aktivitasnya dengan aman, tertib dan teratur. Menjaga struktur keamanan Negara merupakan tugas-tugas yang berada diluar bidang kepolisian negara merupakan masalah spesifik yang ditangani oleh Polisi Pamong Praja antara lain menangani bidang pemeritahan umum, khususnya dalam pembinaan ketenteraman dan ketertiban di daerah.

Polisi pamong Praja baik sebagai personel maupun institusi yang menangani bidang ketenteraman dan ketertiban umum berkembang sejalan dengan luasnya cakupan tugas dan kewajiban kepala daerah dalam menyelenggarakan bidang pemerintahan. Pemeliharaan ketenteraman dan ketertiban merupakan kebutuhan mutlak yang menjadi tugas bersama antara pemerintah dan masyarakat.

Tugas Satuan Polisi Pamong Praja hakikatnya mengikat hubungan antara anggota/kelompok/anggota masyarakat dengan pemerintah, pada dasarnya merupakan tiga pilar yang saling berkait satu dengan yang lain dan tidak bisa dipisahkan. ketiga pilar itu adalah : Pertama, ketenteraman merupakan perasaan jiwa orang (anggota masyarakat) yang menikmati hidupnya dengan nyaman bebas dari gangguan dan ancaman baik fisik maupun spikis. Segala aktivitas, kreativitas, produktivitas warga masyarakat dapat dilakukan tanpa dihantui rasa ketakutan dan kekhawatiran. Kedua, ketenteraman adalah suatu tatanan dalam suatu lingkungan kehidupan yang terwujud oleh adanya perilaku manusia, baik pribadi maupun sebagai anggota masyarakat yang mematuhi kaidah norma agama, norma sosial dan perundang-undangan yang berlaku. Ketiga, tegaknya peraturan-peraturan (temasuk norma dan nilai-nila) merupakan sarana penting bagi terwujudnya ketertiban.

Ketertiban tidak tercipta jika peraturan-peraturan tidak diupayakan tegak sebagaiman mestinya, jika peraturan tidak ditegakkan, maka yang tumbuh subur adalah sikap anarki yang cenderung menghalalkan segala cara dan tindakan asal kepentingan sendiri terpenuhi. Ketiga pilar ini perlu dimaknai secara mendalam oleh seluruh aparat Polisi Pamong Praja dalam mengemban tugasnya yang tidak ringan dan penuh tantangan ini. Dalam melakukan tugasnya aparat Polisi Pamong Praja seringkali berhadapan dengan masyarakat yang memiliki kepentingan tertentu dalm memperjuangkan kehidupanya. Akhirnya tidak jarang menimbulakan sikap untuk cenderung melakukan hal-hal yang bertentangan ketentuan peraturan yang ada. 


\section{Tugas dan Kewajiban Satpol PP}

Satpol PP dan WH Kabupaten Aceh Barat mempunyai tugas menegakkan Qanun dan menyelenggarakan ketentraman dan ketertiban umum serta perlindungan masyarakat dan penegakan syariat islam. Untuk melaksanakan tugas tersebut, Satpol PP dan WH Kabupaten Aceh Barat menyelenggarakan fungsi:

a. Menyusun program dan melaksanakan penegakan Qanun, menyelenggarakan ketertiban umum dan ketentraman masyarakat serta perlindungan masyarakat;

b. Melaksanakan kebijakan penegakan Qanun dan peraturan kepala daerah;

c. Melaksanakan kebijakan penyelenggaraan ketertiban umum dan ketentraman masyarakat di daerah;

d. Melaksanakan kebijakan perlindungan masyarakat;

e. Melaksanakan koordinasi penegakan Qanun dan peraturan kepala daerah, menyelenggarakan ketertiban umum dan ketentraman masyarakat dengan Kepolisian Negara Republik Indonesia, penyidik pegawai negeri sipil daerah dan /atau aparatur lainnya;

f. Melakukan pengawasan terhadap masyarakat, aparatu,r atau badan hukum agar mematuhi dan mentaati perda dan peraturan kepala daerah;

g. Melakukan pengawasan terhadap pelaksanaan dan pelanggaran peraturan perUndang-Undangan dibidang Syariat Islam;

h. Melakukan pembinaan dan advokasi spiritual terhadap setiap orang berdasarkan bukti permulaan patut diduga telah melakukan pelanggaran terhadap peraturan perUndang-Undangan dibidang Syariat Islam;

i. Melimpahkan perkara pelanggaran peraturan per-Undang-Undangan dibidang Syariat Islam kepada penyidik;

j. Menberitahukan kepada masyarakat tentang adanya peraturan per-UndangUndangan dibidang Syariat Islam;

k. Menemukan adanya perbuatan pelanggaran terhadap ketentuan Syariat Islam;

1. Menegur, memperingatkan dan menasehati seseorang yang patut diduga telah melakukan pelanggaran terhadap ketentuan Syariat Islam;

m. Berupaya untuk menghentikan kegiatan/ perbuatan yang patut diduga telah melanggar peraturan per-Undang-Undangan dibidang Syariat Islam;

n. Menyelesaikan perkara pelanggaran tersebut malalui rapat adat Gampong;

o. Memberitahukan pihak terkait tentang adanya dugaan telah terjadi penyalahgunaan izin penggunaan suatu tempat sarana; dan

p. Pelaksanaan tugas-tugas lainnya yang diberikan oleh Kepala Daerah sesuai dengan bidang tugas dan fungsinya.

Selanjutnya dalam Bab III (8) Peraturan Pemerintah Nomor 6 Tahun 2010 disebutkan mengenai kewajiban Sappol PP dan WH dalam melaksanakan tugasnya, yakni :

6. Menunjang tinggi norrna hukum, norma agama, hak asasi manusia, dan norma sosial lainnya yang hidup dan berkembang di masyarakat

7. Menaati disipilin pegawai negeri sipil dan kode etik polisi pamong praja

8. Membantu menyelesaikan perselisihan masyarakat yang dapat mengganggu ketertiban umum dan ketentraman masyarakat

9. Melaporkan kepada Kepolisian Negara Republik Indonesia atas ditemukannya atau patut diduga atas adanya tindak pidana

10. Menyerahkan kepada penyidik Pegawai Negeri Sipil daerah atas ditemukannya atau patut diduga atas adanya pelanggaran terhadap perda dan/atau peraturan kepala daerah. 
Adapun kewenangan yang diberikan kepada Satpol PP dan WH Kabupaten Aceh Barat sesuai dengan peraturan Bupati Aceh Barat Nomor 26 Tahun 2011 Tentang Penjabaran Tugas, Fungsi dan Tata Kerja Satpol PP dan WH Kabupaten Aceh Barat antara lain adalah :

a. Melakukan tindakan penertiban non yustisial terhadap warga masyarakat, aparatur, atau badan hukum yang melakukan pelanggaran atas Qanun atau Peraturan Kepala Daerah;

b. Menindak warga masyarakat, aparatur, atau badan hukum yang mengganggu ketertiban umum dan ketentraman masyarakat;

c. Dan pemberdayaan kapasitas Fasilitas penyelenggaraan perlindungan masyarakat;

d. Melakukan tindakan penyelidikan terhadap warga masyarakat, aparatur, atau badan hukum yang diduga melakukan pelanggaran atas Qanun dan Kepala Daerah;

e. Melakukan tindakan administratif warga masyarakat, aparatur,badan hukum yang melakukan pelanggaran atas Qanun dan Peraturan Kepala Daerah;

f. Melakukan pengawasan terhadap pelaksanaan peraturan per-Undang-Undangan dibidang Syariat Islam;

g. Menegur, menasehati, mencegah dan melarang setiap orang patut diduga talah, sedang dan melakukan pelanggaran terhadap peraturan per-Undang-Undangan dibidang Syariat Islam;

h. Menerima laporan pengaduan dari masyarakat;

i. Menyuruh berhenti seseorang yang patut diduga sebagai pelaku pelanggaran;

j. Meminta keterangan identitas setiap orang yang patut diduga telah sedang melakukan pelanggaran;

k. Menghentikan kegiatan yang patut diduga melanggar peraturan per-UndangUndangan dibidang Syariat Islam;

1. Dalam proses pembinaan berwenang meminta bantuan kepada Kechik dan Tuha Peut setempat;

m. Menjalankan tugas pembinaan terhadap seseorang yang diduga melakukan pelanggaran dan diberi kesempatan maksimal 3 (tiga) kali dalam masa tertentu; dan

n. Setiap orang yang pernah mendapat pembinaan petugas muhtasib, tetapi masih melanggar, akan diajukan kepada penyidik.

\section{Visi dan Misi}

Visi Satuan Polisi Pamong Praja dan Wilayatul Hisbah (Satpol PP dan WH) Kabupaten Aceh Barat sebagai sebuah lembaga penegakan Qanun di bidang ketentraman dan ketertiban umum Syariat Islam adalah "Terwujudnya ketentraman dan ketertiban umum dalam masyarakat yang berdasarkan Dinul Islam".

Berikut ini adalah Misi Satuan Polisi Pamong Praja dan Wilayatul Hisbah Kabupaten Aceh Barat:

1. Meningkatkan kemitraan dengan Alim Ulama, Tokoh Masyarakat, Aparatur Pemerintah dan Masyarakat pada umumnya dalam proses penertiban dan implementasi Syariat Islam.

2. Meningkatkan Qanun/ Perda dan keputusan Kepala Daerah tentang penertiban Syariat Islam.

3. Meningkatkan penertiban Qanun/Perda dan penyelenggaraan ketertiban umum dan ketentraman masyarakat.

4. Meningkatkan mutu dan citra sumber daya manusia dibidang Satuan Polisi Pamong Praja dan Wilayatul Hisbah.

5. Meningkatkan sarana dan pengembangan prasarana Satuan Polisi Pamong Praja dan Wilayatul Hisbah.

Kinerja pelayanan Satpol PP dan WH Kabupaten Aceh Barat dibidang penegakan Qanun telah membawa perubahan yang positif di masyarakat namun perkembangan kualitas aspirasi 
dan partisipasi sebagai tolak ukur dari keberhasilan bidang ini belum menunjukkan hasil yang signifikan. Berbagai persoalan seperti belum adanya tindak lanjut dari hasil penertiban yang dilakukan, sebagai contoh penertiban para pedang liar dan pedagang musiman setelah dilakukan penertiban, pihak Satpol PP dan WH tidak tahu harus mengarahkan para pedagang tersebut kemana karena belum adanya lokasi berjualan yang permanen bagi setiap mereka, selanjutnya penertiban ternak yang belum adanya lokasi karantina hewan sehingga hewan-hewan hasil tangkapan tidak tahu mau dibawa kemana begitu pula dengan penegakan syariat islam, tidak biasanya Satpol PP dan WH untuk memberikan tindakan berupa sanksi hukum bagi para pelaku.

Satuan Polisi Pamong Praja ( Satpol PP) sebagai aparatur pemerintah yang sekaligus inti dari masyarakat dituntut untuk melakukan perbaikan dan peningkatan kemampuannya secara terus menerus dan berkeseimbangan Satuan Polisi Pamong Praja memiliki misi strategis dalam membantu kepala Daerah untuk menciptakan kondisi Daerah yang tentram, tertib dan teratur sehingga penyelenggaraan roda pemerintahan dapat berjalan dengan lancar dan masyarakat dapat melakukan kegiatan dengan aman. Oleh karena itu, disamping menegakkan peraturan Daerah, Polisi Pamong Praja juga dituntut untuk menegakkan kebijakan Pemerintah Daerah lainnya yaitu Keputusan, Kepala daerah salah satunya adalah penertiban pedagang kaki lima yang melakukan kegiatan dagangnya dibadan jalan yang dapat merugikan masyarakat banyak.

Lebih lanjut Satpol PP tetap dipertahankan keberadaanya dalam rangka penyelenggaraan Pemerintahan Daerah berdasarkan Undang-Undang Nomor 9 Tahun 2015 tentang perubahan kedua atas Undang-Undang Nomor 23 Tahun 2014 Tentang Pemerintahan Daerah. Oleh karena itu Satpol PP merupakan aparat yang sangat dibutuhkan oleh kepala daerah dalam memelihara ketentraman, ketertiban umum dan penegakan Qanun.

\section{Asas-Asas Pemerintah Daerah}

Dalam penyelenggaran pemerintahan, ada beberapa prinsip daerah yang menjadi pegangan oleh aparat pemerintahan dalam menggerakkan administrasi pemerintahan atau manajemen pemerintahan. Prinsip - prinsip dasar tersebut disebut dengan asas - asas pemerintahan. Sentralisasi, dekonsentrasi, dan desentralisasi adalah konsep - konsep yang berhubungan dengan pengambilan keputusan dalam organisasi termasuk dalam organisasi Negara. (Nurcholis, 2007:3).

\section{Asas Desentralisasi}

Asas desentralisasi adalah penyerahan urusan pemerintahan dari pemerintah atau daerah tingkat atasnya kepada daerah yang menjadi urusan rumah tangganya. Ditinjau dari segi pemberian wewenangnya asas desentralisasi adalah asas yang akan memberikan wewenang kepada pemerintah daerah untuk mengatur dan menagani urusan- urusan tertentu sebagai urusan rumah tangganya sendiri.Adanya pemerintahan daerah dimulai dari kebijakan desentralisasi. Desentralisasi berasal dari bahasa latin, yaitu De yang berarti lepas dan Centrum yang berarti pusat. Decentrum berarti melepas dari pusat. Dengan demikian, desentralisasi bersarti melepas atau menjauh dari pemusatan. Desentralisasi tidak putus sama sekali dengan pusat tapi hanya menjauh dari pusat.

Organisasi yang besar dan kompleks seperti Negara Indonesia tidak akan efisien jika semua kewenangan politik dan administrasi diletakkan pada puncak hirearki organisasi / pemerintah pusat, karena pemerintah pusat akan menanggung beban yang berat. Juga tidak cukup hanya dilimpahkan secara dekonsentrasi kepada pejabatnya yang berada di wilayah Negara. Agar kewenangan tersebut dapat diimplementasikan secara efisien dan akuntabel, maka sebagian kewenangan poltik dan administrasi pada organisasi yang lebih rendah disebut desentralisasi. 
Karena jenjang hierarki yang lebih rendah (pemerintah daerah) tersebut diserahi wewenang penuh, baik politik maupun administrasi, maka pada jenjang organisasi yang diberi penyerahan wewenang tersebut timbul otonomi. Otononi artinya kebebasan masyarakat yang tinggal di daerah yang bersangkutan untuk mengatur dsan mengurus kepentingannya yang bersifat lokal, bukan yang bersifat nasional. Karena itu, desentralisasi menimbulkan otonomi daerah, yaitu kebebasan masyarakat yang tinggal di daerah otonom untuk mengatur dan mengurus kepentingannya yang bersifat lokal. Jadi, otonomi daerah adalah konsekuensi logis penerapan asas desentralisasi pada pemerintahan daerah.

Henry Maddick menjelaskan, desentralisasi adalah penyerahan kekuasaan secara hukum untuk menangani bidang - bidang / fungsi - fungsi tertentu kepada daerah otonom. (Nurcholis, 2007:10). J. Riwu Kaho (1997:5) mengatakan Republik Indonesia adalah Negara Kesatuan yang didesentralisasikan. Alasan diterapkannya asas desentralisasi adalah pelaksanaan asas desentralisasi akan membawa efektifitas dalam pemeintahan, sebab wilayah Negara itu pada umumnya terdiri pada berbagai satuan daerah yang masing - masing memilikki sifat khusus tersendiri yang disebabkan oleh faktor - faktor geografis (keadaan tanah, iklim, flora, fauna, adat - istiadat, kehidupan ekonomi, bahasa, tingkat pendidikan / pengajaran, dan sebagainya). Pemerintahan dapat efektif kalau sesuai dan cocok dengan keadaan riil dalam Negara.

\section{Asas Dekonsentrasi}

Pengertian Dekonsentrasi adalah pelimpahan wewenang dari pemerintah pusat kepada daerah sebagai wakil pemerintah dan / atau perangkat pusat di daerah. Dalam Negara kesatuan seperti Indonesia, pelimpahan wewenang tersebut adalah dari pemerintah pusat kepada gubernur sebagi wakil pemerintah dan / atau perangkat pusat di daerah disebut juga dengan instansi vertikal, yaitu perangkat departemen dan / atau lembaga pemerintah non departemen di daerah (UU Nomor 9 Tahun 2015).

Dekonsentrasi sebenarnya sentralisasi juga tapi lebih halus dari pada sentralisasi. Dekonsentrasi adalah pelimpahan wewenang administrasi dari pemeintah pusat kepada pejabatnya yang berada pada wilayah Negara di luar kantor pusatnya. Dalam konteks ini yang dilimpahkan adalah wewenang administrasi bukan wewenang politik tetap dipegang oleh pemerintah pusat.

Pejabat pemerintah pusat yang berada di wilayah Negara adalah pejabat yang diangkat oleh pemerintah pusat, dan ditempatkan pada wilayah - wilayah tertentu sebagai wilayah kerjanya. Rondinelli menjelaskan bahwa dekonsentrasi adalah penyerahan sejumlah kewenangan atau tanggung jawab administrasi kepada cabang departemen atau badan pemerintah yang lebih

rendah. Harold F. Aldefer menjelaskan, pelimpahan wewenang dalam bentuk dekonsentrasi semata - mata menyusun unit administrasi baik tunggal ataupun dalam hirarki, baik itu terpisah ataupun tergabung, dengan perintah mengenai apa yang seharusnya mereka kerjakan atau bagaimana mengerjakannya.

Dalam dekonsentrasi tidak ada kebijakan yang dibuat ditingkat lokal serta tidak ada keputusan fundamental yang diambil. Badan- badan pusat memiliki semua kekuasaan dalam dirinya sementara pejabat lokal merupakan bawahan sepenuh - penuhnya dan mereka hanya menjalankan perintah.

Dalam dekonsentrasi yang dilimpahkan hanya kebijakan administrasi (impelementasi kebijakan politik) sedangkan kebijakan politiknya tetap berada pada pemerintah pusat. Oleh karena itu, pejabat yang diserahi pelimpahan wewenang tersebut adalah pejabat yang mewakili pemerintah pusat, bukan dipilih oleh rakyat yang dilayani. Karena itu, pejabat tersebut bertanggung jawab kepada pejabat yang mengangkatnya yaitu pejabat pusat, bukan kepada rakyat yang dilayani. 


\section{Asas Tugas Pembantuan}

Asas tugas pembantuan, yaitu "penugasan" dari pemerintah kepada daerah dan atau desa: dari pemerintah provinsi kepada pemerintah kabupaten atau kota dan atau desa: serta dari pemerintah kabupaten atau kota kepada desa untuk melaksanakan tugas tertentu. Pengertian asas tugas pembantuan ialah tugas yang diberikan dari instansi atas kepada instansi bawahan yang berada di daerah sesuai arah kebijakan umum yang ditetapkan oleh instansi yang memberikan penugasan, dan wajib mempertanggungjawabkan tugasnya itu kepada instansi yang memberikan penugasan.

\section{Qanun}

\section{Kedudukan Qanun}

Undang-Undang Nomor 11 Tahun 2006 tentang Pemerintahan Aceh merupakan tatanan hukum dalam sistem hukum dan sistem perundang-undangan nasional. Dalam Pasal 1 angka 21 Undang-Undang No.11 Tahun 2006, ditentukan bahwa "Qanun Aceh adalah peraturan perundang-undangan sejenis peraturan daerah provinsi yang mengatur penyelenggaraan pemerintahan dan kehidupan masyarakat Aceh." Dalam Pasal 233 ayat (1) ditentukan bahwa "qanun dibentuk dalam rangka penyelenggaraan Pemerintahan Aceh, pemerintahan kabupaten/kota, dan penyelenggaraan tugas pembantuan."

Undang-Undang No. 9 Tahun 215 Tentang Perubahan Kedua Atas Undang-Undang No. 23 Tahun 2014 Tentang Pemerintahan Daerah, dalam Pasal 136 ayat (2) ditegaskan bahwa "peraturan daerah dibentuk dalam rangka penyelenggaraan otonomi daerah provinsi/kabupaten/kota dan tugas pembantuan." Pada ayat (3) pasal yang sama ditentukan lebih lanjut bahwa peraturan daerah merupakan penjabaran lebih lanjut dari peraturan perundangundangan yang lebih tinggi dengan memperhatikan ciri khas masing-masing daerah.

Dalam Pasal 1 angka 8 Undang-Undang No. 12 Tahun 2011 Tentang Pembentukan Peraturan Perundang-undangan ditentukan bahwa "peraturan daerah kab/kota adalah peraturan perundang-undangan yang dibentuk oleh Dewan Perwakilan Rakyat Daerah Kab/Kota dengan persetujuan bersama Bupati/Walikota." Kemudian dalam Pasal 14 Undang-Undang Nomor 12 Tahun 2011 Tentang Pembentukan Peraturan Perundang-undangan ditentukan bahwa "materi muatan peraturan daerah provinsi/kota adalah seluruh materi muatan dalam rangka penyelenggaraan otonomi daerah dan tugas pembantuan, serta menampung kondisi khusus daerah dan atau penjabaran lebih lanjut peraturan perundang-undangan yang lebih tinggi."

Dapat disimpulkan bahwa Qanun merupakan salah satu bentuk hukum tertulis dalam sistem perundang-undangan nasional, yang sejenis dengan Peraturan Daerah. Numum secara khusus isinya berbeda, oleh karena kewewenangan mengatur dan materi muatan tertentu dalam qanun didasarkan pada ketentuan dalam Undang-Undang No. 11 Tahun 2006. Sedangkan materi muatan "peraturan daerah" yang secara umum berpedoman pada ketentuan Undang-Undang No. 9 Tahun 215 Tentang Perubahan Kedua Atas Undang-Undang No. 23 Tahun 2014 Tentang Pemerintahan Daerah.

Pemerintah Aceh berdasarkan ketentuan Undang-Undang No. 11 Tahun 2006 mempunyai kewewenang spesifik untuk mengatur beberapa hal tertentu sebagai materi muatan qanun, misalnya tentang pelaksanaan syari'at Islam. Kewenangan ini secara hukum adalah sah, sebagai kewenangan atribusi (attributie van bevoegheid), yang diciptakan atau dibentuk oleh pembentuk undang-undang (DPR), yang sebelumnya tidak ada, dan secara khusus diadakan untuk itu.

Dengan demikian Qanun merupakan bagian dari sistem perundang-undangan nasional, dan oleh karena itu norma atau kaedah hukum yang diatur atau materi muatan dalam Qanun merupakan sub sistem dari sistem hukum nasional. Disebut "sub sistem" oleh karena wilayah berlakunya adalah khusus atau bersifat lokal. Walaupun berlakunya pada wilayah khusus akan tetapi penegakan hukumnya tetap melibatkan institusi dalam sistem peradilan nasional (UU No. 9 Tahun 2015). 
Dalam sistem peraturan perundang-undangan, bahwa secara hukum kedudukan atau eksistensi qanun sangat jelas, merupakan bagian dari sistem perundang-undangan nasional.

\section{Tujuan dan Fungsi Qanun}

Qanun sebagai peraturan perundang-undangan daerah dibuat untuk menyelenggarakan urusan pemerintahan Aceh. Qanun tersebut merupakan bagian yang tak terpisahkan dari kesatuan sistem perundang-undangan nasional. Sistem perundang-undangan Republik Indonesia diatur dalam tata urutannya menurut ketentuan Pasal 7 ayat (1) Undang-Undang Nomor 12 Tahun 2011 Tentang Pembentukan Peraturan Perundang-undangan, ditegaskan bahwa jenis dan hirarki peraturan perundang-undangan adalah (UU Nomor 11 Tahun 2011).
a. UUD.
b. Ketetapan MPR.
c. Undang-Undang/Perpu.
d. Peraturan Pemerintah.
e. Peraturan Presiden.
f. Peraturan Daerah Provinsi.
g. Peraturan Daerah Kabupaten/Kota

Mengenai qanun sebagai jenis peraturan perundang-undangan untuk penyelenggaraan pemerintahan Aceh tidak disebutkan dalam Pasal 7 ayat (1) Undang-undang Nomor 12 Tahun 2011 Tentang Pembentukan Peraturan Perundang-undangan. Akan tetapi keberadaan Qanun dapat dilihat atau ditelusuri dalam sumber hokum yang utama, yakni Pasal 18B Undang-Undang Dasar 1945.

Peraturan Daerah, untuk Provinsi Nanggroe Aceh Darussalam disebut dengan Qanun. Hal ini ditegaskan dalam Pasal 30 Undang-undang Nomor 18 Tahun 2001 Tentang Otonomi Khusus Bagi Provinsi Daerah Istimewa Aceh Sebagai Provinsi Nanggroe Aceh Darussalam, yang sudah dicabut dengan Undang-undang Nomor 11 Tahun 2006 Tentang Pemerintahan Aceh, ditetapkan bahwa "semua peraturan daerah yang ada dinyatakan sebagai Qanun Provinsi Nanggroe Aceh Darussalam sesuai dengan yang dimaksud dengan undang-undang ini".

Dalam penjelasan umum Undang-undang Nomor 11 Tahun 2006 Tentang Pemerintahan Aceh menyebutkan bahwa Qanun Provinsi Nanggroe Aceh Darussalam, yang dapat mengenyampingkan peraturan perundang-undangan yang lain dengan mengikuti asas Lex Specialis Derogaat Lex Generalis dan Mahkamah Agung berwenang melakukan uji materil terhadap Qanun (Yoesoef, 2009:181). Keterkaitan dengan tata urutan perundang-undangan menurut Undang-undang Nomor 12 Tahun 2011 diatas, maka telah menempatkan "Qanun" sebagai subsistem perundang-undangan nasional bahkan sistem hukum nasional pada umumnya. Karena itu Qanun tidak boleh bertentangan dengan peraturan perundang-undangan yang lebih tinggi tingkatnya (Bagir Manan, 1995:9).

Dari uraian di atas dapat dipahami bahwa Qanun Provinsi Nanggroe Aceh Darussalam berfungsi sebagai berikut : (Yoesoef, 2009:182).

a. Menyelenggarakan pengaturan hal-hal yang tidak bertentangan dengan peraturan perundang-undangan yang lebih tinggi (peraturan perundang-undangan tingkat pusat).

b. Menyelenggarakan pengaturan hal-hal yang belum diatur oleh peraturan perundangundangan yang lebih tinggi. Fungsi ini memperjelas ketentuan yang diatur dalam Pasal 270 ayat (1) ayat (2) dan (3) Undang-undang Nomor 11 Tahun 2006 Tentang Pemerintahan Aceh yang menetapkan bahwa "ketentuan pelaksana undang-undang ini yang menyangkut kewenangan pemerintah ditetapkan dengan peraturan perundang-undangan (peraturan pemerintah), dan ketentuan yang menyangkut kewenangan pemerintah provinsi dan kabupaten/kota Nanggroe Aceh Darussalam ditetapkan dengan Qanun. 
Sedangkan beberapa pakar hukum juga mengemukakan tujuan dan fungsi dari Qanun adalah sebagai berikut: (Husni Jalil, 2013).

a. Melaksanakan perintah Undang-undang Nomor 11 Tahun 2006 Tentang Pemerintah Aceh.

b. Fungsinya untuk mengisi kekosongan hukum di daerah dalam rangka pelaksanaan otonomi daerah.

Kedudukan Qanun sesuai dengan penyelenggaraan otonomi khusus bagi Provinsi Nanggroe Aceh Darussalam perlu makin dikukuhkan kedudukannya yang dapat bersifat mandiri, dari segi pembuatannya sudah semestinya kedudukan Qanun ini dapat dilihat setara dengan Undang-undang dalam arti sama-sama merupakan produk hukum lembaga legislatif, namun demikian dari segi pengaturan materi dalam ruang lingkup daerah yang berlaku di wilayah yang lebih sempit, maka dianggap mempunyai kedudukan lebih rendah dibandingkan dengan ruang lingkup wilayah berlakunya undang-undang.

Undang-undang lebih tinggi kedudukannya dari pada Qanun. Karena itu sesuai prinsip hirarki peraturan perundang-undangan, peraturan yang lebih rendah itu tidak boleh bertentangan dengan peraturan yang derajatnya lebih tinggi. Akan tetapi, sebagai konsekuensi diberikannya otonomi khusus bagi provinsi Naggroe Aceh Darussalam maka produk legislatif daerah ini dapat saja menyimpang dengan produk eksekutif di tingkat pusat. Misalnya suatu materi qanun/perda yang telah ditetapkan secara sah ternyata bertentangan isinya dengan materi peraturan menteri di tingkat pusat maka pengadilan haruslah menertibkan bahwa qanun itulah yang berlaku sepanjang untuk daerahnya sedangkan peraturan Menteri dimasudkan untuk peraturan yang berlaku umum di seluruh Indonesia. (Yoesoef, 2009:183).

\section{Perbedaan Peraturan Daerah dan Qanun Peraturan Daerah}

Peraturan perundang-undangan tingkat daerah diartikan sebagai peraturan peraturan perundang-undangan yang dibentuk oleh pemerintah daerah atau salah satu unsur pemerintah daerah yang berwenang membuat peraturan perundang-undangan daerah. Peraturan daerah (perda) ditetapkan oleh kepala daerah setelah mendapatkan persetujuan bersama Dewan Perwakilan Rakyat. Ketentuan ini mengikuti semangat rumusan UUD 1945 Pasal 5 ayat (1) yang menyebutkan "Presiden memegang kekuasaan membentuk undang-undang dengan persetujuan Dewan Perwakilan Rakyat". Dengan demikian dapat diartikan bahwa Peraturan Daerah itu semacam undang-undang (pada tingkat daerah).

Meskipun Undang-undang menyebutkan bahwa Kepala Daerah menetapkan Peraturan daerah setelah mendapat persetujuan Dewan Perwakilan Rakyat Daerah, tidak berarti semua kewenangan membuat peraturan daerah ada pada kepala daerah dan Dewan Perwakilan Rakyat Daerah hanya memberikan persetujuan. Dewan Perwakilan Rakyat Daerah memiliki kekuasaan yang juga menentukan dalam pembentukan peraturan daerah. DPRD dilengkapi dengan hak-hak inisiatif dan hak mengadakan perubahan. Bahkan persetujuan itu sendiri mengandung kewenangan menentukan (dicicive). Tanpa persetujuan DPRD tidak akan ada peraturan daerah. Karena itulah tidak berlebihan kalau Pasal 136 Undang-undang Nomor 32 Tahun 2004 Tentang Pemerintah Daerah ditentukan " pembuatan peraturan daerah dilakukan bersama-sama oleh Kepala Daerah dan Dewan Perwakilan Daerah (Abdul Latief, 2005:59).

Peraturan Daerah dibentuk berdasarkan asas pembentukan peraturan perundang-undangan yang meliputi: (Widjaja, 2005: 244)

1. Kejelasan tujuan

2. Kelembagaan atau organ pembentuk yang tepat

3. Kesesuaian antara jenis

4. Dapat dilaksanakan

5. Kedayagunaan dan kehasilgunaan 
6. Kejelasan rumusan

7. Keterbukaan

Sedangkan materi muatan dalam Peraturan Daerah mengandung asas sebagai berikut: (Widjaja, 2005: 245)

1. Pengayoman

2. Kemanusiaan

3. Kebangsaan

4. Kekeluargaan

5. Kenusantaraan

6. Bhineka tunggal ika

7. Keadilan

8. Kebersamaan kedudukan dalam hukum dan pemerintahan

9. Ketertiban dan kepastian hukum

10. Keseimbangan, keselarasan dan keserasian

Selanjutnya ada beberapa daerah yang memiliki Perda Syariah dimana tujuan dari pembentukan Peraturan Daerah tersebut untuk menciptakan masyarakat yang mencintai budaya islam dan adat istiadat daerah tersebut. Di dalam penerapan sanksinya Perda Syariah menerapkan sanksi administrasi, dimana sanksi dari pelanggaran Perda Syariah dikenakan teguran secara lisan dan tulisan. Sebagai contoh Perda No 6 Tahun 2005 Tentang Berpakaian Muslim dan Muslimah Kabupaten Solok Selatan. Di dalam penjelasan Pasal 3 Perda No 6 Tahun 2005 Tentang Berpakaian Muslim dan Muslimah Kabupaten Solok Selatan menyatakan (Perda No. 6 Tahun 2005).

1. Membentuk sikap sebagai seorang muslim dan muslimah yang baik dan beraklhak mulia.

2. Membiasakan diri berpakaian muslim dan muslimah dalam kehidupan sehari-hari baik dalam kehidupan bekeluarga maupun dihadapan umum.

3. Menciptakan masyarakat yang mencintai budaya islam dan budaya minangkabau

4. Melestarikan fungsi adat sesuai dengan pituah "syara mangato adat mamakai".

Di dalam Pasal 5 Perda Nomor 6 Tahun 2005 Tentang Berpakaian Muslim dan Muslimah di Kabupaten Solok Selatan, dijelaskan kewajiban dan pelaksanaan. Menurut ketentuan Pasal 5 Perda Nomor 6 Tahun 2005 Tentang Berpakaian Muslim dan Muslimah yang berkewajiban berbusana muslim dan muslimah hanya pelajar baik di tingkat SD,SMP,SMU dan karyawan/karyawati, sedangkan mahasiswa/mahasiswi, TNI dan POLRI dan masyarakat umum bersifat himbauan.

Dalam uraian tersebut maka dapat disimpulkan bahwa Peraturan Daerah dibuat karena ada perintah dari Undang-undang Nomor 12 Tahun 2008 Tentang Perubahan Kedua atas Undangundang Nomor 32 Tahun 2004 Tentang Pemerintah Daerah dan juga Undang-undang Nomor 12 Tahun 2011 Tentang Pembentukan Peraturan Perundang-undangan.

\section{Qanun}

Qanun adalah peraturan perundang-undangan sejenis peraturan daerah yang mengatur penyelengaaraan pemerintahan dan kehidupan masyarakat Aceh. Sedangkan Qanun kabupaten/kota adalah peraturan perundang-undangan sejenis peraturan daerah kabupaten/kota yang menyelenggarakan pemerintahan dan kehidupan masyarakat kabupaten/kota di Aceh (UU No. 11 Tahun 2006).

Undang-undang Nomor 11 Tahun 2006 Tentang Pemerintahan Aceh dalam Pasal 237 ayat (1) menentukan bahwa untuk membentuk qanun harus mengandung asas: (UU No. 11 Tahun 2006).

1. Pengayoman

2. Kemanusiaan 
3. Kebangsaan

4. Kekeluargaan

5. Keanekaragaman

6. Keadilan

7. Nondiskriminasi

8. Kebersamaan kedudukan dalam hukum dan pemrintahan

9. Ketertiban

10. Kepastian hukum

11. Keseimbangan, keserasian, kesetaraan dan keselarasan

Qanun Aceh disahkan oleh kepala daerah dalam hal ini Gubernur setelah mendapatkan persetujuan bersama Dewan Perwakilan Rakyat Aceh selanjutnya Qanun Kabupaten/Kota disahkan oleh kepala daerah dalam hal ini Bupati/Walikota setelah mendapatkan persetujuan bersama Dewan Perwakilan Rakyat Kota. Mengenai Qanun sebagai jenis peraturan perundangundangan untuk penyelenggaraan pemerintahan aceh tidak disebutkan dalam Undang-undang Nomor 12 Tahun 2011 Tentang Pembentukan Peraturan Perundang-undangan. Akan tetapi keberadaan Qanun dapat ditelusuri dalam sumber hukum yang utama, yakni Pasal 18B UUD 1945. Qanun Aceh adalah peraturan daerah Provinsi Nanggroe Aceh Darussalam, yang dapat mengenyampingkan peraturan perundang-undangan yang lain dengan mengikuti asas Lex specialis derogate Lex Generalis, dan Mahkamah Agung dapat melakukan uji materil terhadap Qanun.

Di dalam Qanun Nomor 5 Tahun 2011 Tentang Tata Cara Pembentukan Qanun disebutkan di dalam Pasal 3 materi muatan Qanun mengandung asas:

1. Dinul islam

2. Sejarah aceh

3. Kebenaran

4. Kemamfaatan

5. Pengayoman

6. Hak asasi manusia

7. Kebangsaan

8. Kekeluargaan

9. Keterbukaan dan komunikatif

10. Keanekaragaman

11. Keadilan

12. Keserasian dan nondiskriminasi

13. Ketertiban dan kepastian hukum

14. Kesamaan kedudukan dalam hukum dan pemerintahan

15. Keseimbangan, kesetaraan dan keselarasan

Materi muatan Qanun adalah seluruh materi muatan dalam rangka penyelenggaraan pemerintahan Aceh sesuai dengan Mou Helsenki 15 Agustus 2005 dan Undang-undang Nomor 11 Tahun 2006 Tentang Pemerintahan Aceh, kecuali dalam hubungan luar negeri, pertahanan luar (TNI), keamanan dalam negeri (Polisi), moneter dan fiskal, kekuasaan kehakiman dan urusan tertentu dalam bidang agama. (Qanun No. 5 Tahun 2011).

Dalam uraian tersebut maka dapat disimpulkan bahwa Qaun dibuat karena ada perintah dari Undang-undang Nomor 11 Tahun 2006 Tentang Pemerintahan Aceh dan juga sumber hukum yang utama Undang Undang Dasar 1945 Pasal 18B. 


\section{Simpulan}

Pertama, Kinerja pelayanan Satpol PP dan WH Kabupaten Aceh Barat dibidang penegakan Qanun telah membawa perubahan yang positif di masyarakat namun perkembangan kualitas aspirasi dan partisipasi sebagai tolak ukur dari keberhasilan bidang ini belum menunjukkan hasil yang signifikan. Berbagai persoalan seperti belum adanya tindak lanjut dari hasil penertiban yang dilakukan, sebagai contoh penertiban para pedang liar dan pedagang musiman setelah dilakukan penertiban, pihak Satpol PP dan WH tidak tahu harus mengarahkan para pedagang tersebut kemana karena belum adanya lokasi berjualan yang permanen bagi setiap mereka, selanjutnya penertiban ternak yang belum adanya lokasi karantina hewan sehingga hewan-hewan hasil tangkapan tidak tahu mau dibawa kemana.

Kedua, Satuan Polisi Pamong Praja ( Satpol PP) sebagai aparatur pemerintah yang sekaligus inti dari masyarakat dituntut untuk melakukan perbaikan dan peningkatan kemampuannya secara terus menerus dan berkeseimbangan Satuan Polisi Pamong Praja memiliki misi strategis dalam membantu kepala Daerah untuk menciptakan kondisi Daerah yang tentram, tertib dan teratur sehingga penyelenggaraan roda pemerintahan dapat berjalan dengan lancar dan masyarakat dapat melakukan kegiatan dengan aman. Oleh karena itu, disamping menegakkan peraturan Daerah, Satuan Polisi Pamong Praja juga dituntut untuk menegakkan kebijakan Pemerintah Daerah lainnya yaitu Keputusan Kepala daerah salah satunya adalah penertiban pedagang kaki lima yang melakukan kegiatan dagangnya dibadan jalan yang dapat merugikan masyarakat banyak.

\section{REFERENSI}

Abdul Latief, 2005. Hukum Dan Peraturan Kebijaksanaan (Beleidsregel) Pada Pemerintahan Daerah, UII Press. Yogyakarta

Bagir Manan, 1995. Sistem dan Teknik Pembuatan Peraturan Perundang-undangan Tingkat Daerah, LPPM-UNISBA. Bandung.

Danim, Sudarman, Dr., Prof. 2002. Menjadi Peneliti Kualitatif, Pustaka Setia. Bandung

Hanif Nurcholis, 2007. "Teori dan Praktik Pemerintahan dan Otonomi Daerah", Penerbit Grasindo. Jakarta

HAW. Widjaja, 1005. Penyelenggaraan Otonomi Di Indonesia Dalam Rangka Sosialisasi Undang-undang Nomor 32 Tahun 2004 Tentang Pemerintahan Daerah, Raja Grafindo Persada. Jakarta

J. Riwu Kaho, 1997.“Prospek Otonomi Daerah di Negara Republik Indonesia”. Rajawali Pers. Jakarta

Mohd. Daud Yoesoef, 2009. Qanun Sebagai Aturan Pelaksana Peraturan Perundangundangan Atasan, Kanun Jurnal Ilmu Hukum No 47 Edisi Agustus 2009. Banda Aceh

Narbuko, Chalid, DRS. Dan Achmadi, Abu. 2004. Metodelogi Penelitian, Rineka Cipta. Jakarta

Sugiyono,2005. Metode Penelitian Kualitatif, Alfabeta. Jakarta

Undang-Undang Nomor 12 Tahun 2011 Tentang Pembentukan Peraturan Perundang-undangan

Undang-Undang No.9 Tahun 2015 Tentang Perubahan Kedua Atas Undang-Undang No 23

Tahun 2014 Tentang Pemerintahan Daerah

Undang-undang Nomor 11 Tahun 2006 Tentang Pemerintahan Aceh

Qanun Nomor 5 Tahun 2011 Tentang Tata Cara Pembentukan Qanun 